\title{
"Lungisa": weaving relationships and social space to restore health in rural KwaZulu Natal
}

\author{
Anette Wickström
}

Linköping University Post Print

\section{Tweet}

N.B.: When citing this work, cite the original article.

Original Publication:

Anette Wickström, "Lungisa": weaving relationships and social space to restore health in rural KwaZulu Natal, 2014, Medical Anthropology Quarterly, (28), 2, 203-220.

http://dx.doi.org/10.1111/maq.12073

Copyright: American Anthropological Association http://www.aaanet.org/

Postprint available at: Linköping University Electronic Press

http://urn.kb.se/resolve?urn=urn:nbn:se:liu:diva-104874 


\title{
"Lungisa" - Weaving Relationships and Social Space to Restore Health in Rural
}

\section{KwaZulu Natal}

Anette Wickström, Linköping university

\begin{abstract}
Many Zulu people who live in big cities in South Africa return to their rural homestead when they fall ill. Although the health care offered in rural areas is not efficient, people wish to connect to their family and ancestors. My aim is to explore acts of lungisa (meaning "to put in order") and what they say about health, agency and the circumstances under which people live. Returning home means weaving oneself firmly within a web of relationships that are located in material things and places. Healing involves imperfect strategies used to better connect bodies, relationships and places. I theorize the acts of returning using Adriana Cavarero's concept "weaving together" and argue that people produce space and relationships over time to exert some control over a life lived under political and economic circumstances that have created separation. Six months of ethnographic field work make up the material for my analysis.
\end{abstract}

Keywords: Zululand, ethnography, illness as disconnection, healing, acts of returning

\section{Introduction}

In September 2004, I spent a holiday in Umhlanga, a wealthy northern suburb of Durban. At the time I was doing fieldwork in Nkolokotho in northeastern rural KwaZulu Natal, an area that was designated as a Zulu homeland under South Africa's former apartheid policy.

Nkolokotho and Umhlanga represent a great contrast in South Africa. In Nkolokotho, the vast majority of households live below the national poverty line and most people are unemployed. The inhabitants live with inadequate health facilities, no drainage, and a substandard water supply, and many are affected by cardiovascular diseases, tuberculosis and HIV. In Umhlanga, by contrast, the inhabitants have experienced the advantages of economic growth in the new South Africa; luxury houses face the sea and whales and dolphins can be spotted from breakfast tables situated on big patios. Early in the morning, many black people jump off the local taxis arriving to Umhlanga to start work in the gardens or houses of wealthy families. Most of these workers live in townships on the outskirts of Durban, in anything from shacks to small houses. Many people there have a strong sense of community and describe 
their home as a sort of native land. From another perspective, the townships are polluted urban areas with no clean water, open sewers, and piles of garbage. Most inhabitants have got a rural home in a longer or shorter distance from Durban. That is the place where they come from and have got their name from, where their extended family and ancestors are.

During my stay, the hostess at my bed and breakfast told me about her gardener. She seemed upset and disappointed when she told me that he had left suddenly after having fallen ill. I understood from her story that he had returned to his rural homestead. To her, his actions seemed useless and irrational. She had wanted him to stay, to receive help and to see a medical doctor in town. Listening to my hostess and trying to imagine her gardener, I thought about how they represented two different narratives. The employer's narrative speaks about trust in, and access to, the health care system in South Africa. It also expresses a wish to help and to get an employee back to work as soon as possible by recommending treatment for the proximate cause of his illness, which involves treating or alleviating the symptoms of the immediate cause, such as germs or viruses. The gardener's narrative, on the other hand, focuses on optimal causes rather than proximate ones. Returning to the rural area means exploring and coming to terms with the underlying cause of an illness experience - finding an explanation for why he fell ill at this point in time. The gardener's narrative also speaks about marginalization in South African society. Poor people cannot afford health insurance and are often left to care for each other in times of illnesses, owing to inefficient medical support and treatment (cf. Du Prez 2008). The two narratives point out differences in material means and cultural meanings, two related aspects of health that I discuss in the present paper.

This fragment from Umhlanga may appear a trifle, but in my experience it was one of many incidents in which a Zulu person's handling of illness was described as incomprehensible. Rituals and social healing do not accord with biomedical assumptions about reasonable behaviour and therefore seem irrational from an outside perspective (cf. Langwick 2011). Hylton White (2001) discusses a case of a family who perform rituals at their rural homestead to improve their life situation. People's efforts are described as successions of feasts in which they are occupied with trying to correct past events. The practice of returning - in order to reestablish connections with the family and ancestors - is described as a dilemma, in the sense that people live in the past rather than in the present. In light of the fact that the family in White's case do not find any obvious solutions to their problems, their concerns appear useless, irrational and naive to the reader. White, though, uses their repeated rituals to 
highlight the social vacuum left in rural areas in South Africa and what globalizing pressures lead to in people's daily lives, thus providing a critique against an intolerable economic and political situation. However, what is needed and what I wish to contribute with my essay is a discussion of the meaning of returning and repetitive actions, not as a dilemma but as logical attempts to act.

My ethnography carried out in Nkolokotho in northeastern KwaZulu Natal, shows that returning and public rituals are important factors in living together (Wickström 2008). The affiliation with the family, both backwards in time with ancestors and forward with future children, is of fundamental value to the individual. Re-establishment of connections with the family and ancestors is central to people's everyday efforts to restore health or keep disease at bay, because the optimal cause of illnesses is thought to be disconnection and noncommunication. The historical process of separation and the experience of unemployment and difficulties in building a home and supporting a family interplay with the representations of illness as disconnection. People in Nkolokotho are eager to find strategies for continuity and clarification of relationships. I have theorized elsewhere (Wickström 2010) that the stubborn maintenance of connecting practices constitutes marginalized people's reaction to their position in the new South Africa, not as an organized resistance movement, but as a form of resistance manifested in daily life. Devisch $(1993 ; 31)$ points out that healing cults act as strongholds against bureaucracy and are generated in relation to the state's hegemonic ideology. In Nkolokotho, the inhabitants use suggestive oppositions such as "the Zulu way" and "as whites do" to accept their situation, but also to resist and produce something of their own. Here I theorize their repetitive actions and acts of returning as imperfect health strategies, and concepts of health and illness as representations that mirror a history of structural constraint and people's experiences of separation. The goal is to challenge or counterpoise the medical science discourse on therapeutic logics, and philosophical theorizing on human agency.

An important part of my material, one that constitutes the essence of the present essay, concerns the concept lungisa, an action that is needed to handle illness or problems in life. Commonly, it refers to what people in Nkolokotho do to be accepted or keep their standing in the community and stay on good terms with others. On rare occasions it means "correcting" a whole life situation. A ritual, in which the person re-establishes relationships to ancestors, is the central feature, and it is probably not performed more than once in a lifetime. Hearing 
about all the measures taken by my informants made me believe I had settled in a community where people envy and are suspicious of each other. With time, however, I found I was living among families who acted with others in mind (cf. Strathern 1988; 272). What I mean is that because relationships are thought to be the basis of good health, consideration for others is central to people's actions, not in the sense of people always being nice, but in the sense of seeing individual actions as affecting others. Procedures of lungisa mean taking responsibility for your health and at the same time for the relationships that are part of producing it.

The informants, however, did not speak of health as solely a matter of the social and cultural environment. People almost always discussed the scarcity of medical doctors, transports, vacant jobs, money and food. Moreover, they regretted what they felt was the degraded moral culture and their marginalized position in the new South Africa. Thus, in my article, I wish to combine cultural analyses of the person and social connections with an analysis of the political economy that has shaped the daily life of people in Nkolokotho, both historically and today. My aim is to explore concepts of health and the relational identity that characterizes how many Zulu people, in this specific context, represent themselves, and moreover, to discuss what the concept of lungisa may say about agency and the circumstances under which people live.

\section{A partible person}

In anthropological writings, the persons I have described so far have been analysed as "partible" entities. "Persons are frequently constructed as the plural and composite site of the relationships that produced them", Strathern says in her work on Melanesians' views on persons $(1988 ; 13)$. Similarly, when my informants talk about health by referring to relationships and family connections, they seem to be part of an "extended body" of those closest to them. Like Niehaus (2002), I found that the concepts of the "partible" person make sense in contemporary contexts in South Africa, despite the current emphasis on individual personhood. The prerequisite of a person's wellbeing is considered to be his/her connection to a homestead and a good relationship with kin and neighbours. However, human efforts to connect body, mind and relationships when dealing with illness are quite similar. What we can see from ethnographies focused on people's handling of illness, even in settings governed by the value of individualism, is that people's experiences are permeated by a sense of relationality. In biomedicine we find similar understandings of disease in the form of psychosomatic diseases and diseases related to stress. Relationships and interaction affect a 
person's wellbeing and sometimes cause ill health. Thus when I speak of a socially connected person, a "partible" or "dividual" person (Strathern 1988), I see the possibility that this may also characterize people who do not consider themselves closely connected (cf. Carsten 2004, Sahlins 2011) - people whose underlying ideology is Western notions of unique and bounded individuals, but who are interwoven in mutually dependant relationships in everyday contexts. Honkasalo (2009) studies suffering from endemic heart disease in North Karelia and theorizes that the core of human agency is to hold on to one's world and protect one's tenuous existence in that world. The women in Honkasalos's study did not try to resist or transform their everyday life, but “to keep one's own and the family's hold on the world, and to reconstitute meaningful webs of kinship, residence, and identity" (p.56 ). In other words, when constantly confronted with difficulties that threatened to destroy their world women acted without an obvious aim to change things, but held on to repetitive activities such as cooking, knitting and taking care of the ancestors on the family pictures. The women tried to repair and fasten social bonds.

Adriana Cavarera (2000[1997]) is an Italian philosopher who speaks about a unique existence, but not as an individual in the sense of 'individual rights'. The uniqueness of each life does not indicate a life lived in isolation but rather 'the togetherness and intercourse' of single living creatures. Being intertwined with other lives is a necessary aspect of an identity. Cavarero (1995[1990]) challenges the notion of rational agency by providing new interpretations of Greek myths, which otherwise are considered universal, logical and the foundation stones of Western theoretical language. She uses images from female mythic figures and provides us with perspectives from a new point of view. In her interpretation of Penelope and her repetitive and unexpected actions, she opens up a broader theoretical understanding of people's attempts to act.

The myth of Odysseus tells us about a man who is travelling and discovering the world while his wife Penelope endures at home, waiting for her husband to return. In her writing, Cavarero moves the focus from Odysseus' productive actions at sea or on unknown shores to a focus on the repetitive actions taking place at home. Penelope is not alone; many suitors are waiting for her answer because they believe Odysseus is dead. However, they cannot force her to answer before she has finished weaving her set of linen. To escape the suitors' pressing proposals, Penelope unravels in the evening what she has woven during the day. The next day she begins weaving again. Penelope's activities, like activities of lungisa, may seem illogical and 
unproductive at first, but in fact, as Cavarero points out, Penelope stops weaving linen and starts weaving time. She weaves a time of repetition and social connection, and in this way rejects the time and place assigned to her.

It may seem farfetched to use an Italian philosopher's writings on female experiences in discussions on Zulu people's situation and efforts to manage sickness. But in fact, there are similarities between the invisibility of female work and experience, as Cavarero shows, and the scepticism towards acts of lungisa that I have met, or in a broader sense towards "the African patient" (e.g. Fanon 1967) and "African healing" (Feierman 1999). When Western and African medicines first met at the beginning of the nineteenth century, their technical knowledge was equally advanced. Doctor Livingstone discussed treatments with traditional healers in Tswana, a neighbouring area to Zululand, and exchanged knowledge about healing and herbs with them. The Africans viewed European therapies as good complements to traditional therapies. However, opposing views of causality and healing was manifested and created misunderstandings. Missionaries in South Africa met people who considered healing to be a matter of interpreting and treating disease as embodied human passions, qualities and evil that both create and destroy local societies (Comaroff \& Comaroff 1997:343). The missionaries viewed bad luck as a cause, rather than seeing the patient as dependant on others, or considering the possibility of treating problems by recreating subverted moral and material relationships (ibid. 1997:347). The colonizers, on their side, tried to fight what they saw as occultism (Feierman 1999). Above all, healing and rituals that involve and target the collective have been subjected to criticism and regulation (e.g. Wickström 2010). Colonial rule fought for managing public healing, which often addressed major outbreaks of disease and starvation, and tried to control rituals intended to heal the political body by warding off witchcraft (Feierman 1999:204). In Zululand, those who had come into power defined crimes as "to practise as, or to consult with, a witch doctor or a diviner" (Parle \& Scorgie 2001). Traditional healing violated the law and "the African patient's" behaviour provoked a distrustful attitude (cf. Fanon 1967) because like Penelope's action, it was unfamiliar and unexpected. Hopefully, Penelope's unpredictable activities of resistance and belonging will shed light on some Zulu people's efforts to re-establish social connections in order to gain health. The connections are fundamental to my informants' understanding of health, and their relational understanding implies a constant balancing and returning, procedures I analyse in my text. But first an introduction of Zululand, my fieldwork and the informants' living conditions are needed. 


\section{Zululand}

Nkolokotho, where I did my field study, is part of an area called Zululand. Zululand was a monarchy in southern Africa during the nineteenth century. Today the term Zululand characterizes the northern part of KwaZulu Natal, one of nine provinces in the new democratic South Africa. During apartheid, the area was designated a Zulu homeland, one of ten homelands in which 75 percent of South Africa's inhabitants were expected to live on 13 percent of the country's area. Inhabitants in the homelands lost their citizenship in South Africa to be citizens in their homelands. In 1948, the apartheid system created health services in the homelands with partition as its goal. The British colonial regime used arguments such as "the healthy reserve" for legitimizing exploitation and segregation (Flikke 2001). Their arguments concealed the fact that the reserves were diseased and impoverished. One year after the apartheid regime fell in 1994, KwaZulu ceased to exist as a homeland.

Three hundred and fifty years of colonization, 45 years of apartheid policy and industrialization have all led to the fragmentation of family relations and have divided families between rural and urban areas. During the $20^{\text {th }}$ century, men were induced to work in the mines close to the big cities, where women and children were not allowed. Then, after the end of apartheid, multinational companies moved to countries with less demanding and less organized workers. Many men lost their jobs and moved back to the rural areas, where it was difficult to make a living (White 2001). Those who found new jobs had to work far away from home.

In Nkolokotho, private life and intimate relationships changed in accordance with wider social changes. During the pre-colonial era, the father of a family provided his sons' means for marriage, and illegitimate children were extremely rare (Bryant 1970). A Zulu marriage was a process more than an event, and a relationship between two families as well as between two people. Gifts were, and still often are, exchanged between the two families over a lifetime. In the 1870s, the colonial regime tried to create marriages that were in order, to break the drawn-out processes and create political order (Welsh 1971). Procedures of returning were seen as disturbing social order, and as a result, women lost their possibility to return home if they were bad treated. Today marriage is dependent on wage labour, and many men cannot afford to pay ilobolo or bride wealth (Hunter 2002). According to parents in Nkolokotho, the biggest problem in life today is that girls get pregnant without a man 
acknowledging paternity and initiating the process of ilobolo. Many young mothers move to the big cities for work, leaving their children with their mothers or grandmothers in Nkolokotho. Returning is a necessary act, as well as a representation of health, though it is often unattainable due to transport costs.

\section{Fieldwork}

In six months in 2004 I did fieldwork in Nkolokotho for my dissertation on the meaning of relationships for health. ${ }^{\mathrm{i}}$ In 2008 and 2011, I made sporadic field visits in Nkolokotho and in townships in the outskirts of Durban, 220 kilometres south, where some of the informants have their second home. I have also had conversations via e-mail and cell phone with some of my interviewees, discussing specific concepts and my interpretations of events. I collected my data by living among the people whose perspective I wished to understand. Family Ndaba, who opened their home to me, and Mr Gumede, the chief in Nkolokotho, were the contacts who opened many doors, made others interested in what I was doing and cared about my security. ${ }^{\text {ii }}$ In order to establish as close and trustful relationships as possible, I visited eight families and ten traditional healers repeatedly over the course of two stays in South Africa. For three months, I lived with one of the families and was able to participate and conduct interviews on a daily basis. For another period of three months, I lived in Mtubatuba, a small town thirty kilometres away, and went to the field five days a week. I learned the basics of isiZulu to be able to join in on elementary conversations but my daily working language was English and the interviews were carried out with the help of an interpreter. During the first period, I travelled in local taxis and vans. These trips became valuable opportunities to chat with both men and women. My presence, as a white woman in an area where whites are almost never seen, created many discussions, and people started conversations as soon as they heard I was interested in health and relationships from their perspective. These informal conversations gave helpful information that sometimes confirmed what I found in the interviews and sometimes deepened or challenged my understanding.

\section{Health and living conditions}

The area of Nkolokotho is almost completely lacking in infrastructure. An unprepared road, which is difficult to use during the rain period, passes through the area. Many Zulu homesteads are spread out over the billowing landscape at a considerable distance from each other. The meeting places are the primary school, the water taps along the bumpy road, and the house where a delegate from the municipality comes once a month to distribute grants to 
people. Two parallel systems of governing and authority exist in Nkolokotho; the municipality located in the nearest town Mtubatuba, and the local authority represented by the chief. Almost every family is dependent on child or elderly grants for their living. Some have started small businesses such as taxi driving, hen raising or road carriers. Those who are employed work in Mtubatuba or as migrant workers.

The living conditions for people in Nkolokotho, as well as for most people living in the townships in Durban, do not include advanced medical care. When people in Nkolokotho fall ill, they seek help from traditional healers as well as from other practitioners. Traditional healers in Nkolokotho are both male and female; they diagnose difficulties people experience in life, prescribe and mix herbal medicines intended to create harmony. People respect and trust their work and try to find their way through a landscape of therapeutic practice that has largely been reconfigured by biomedicine and political steering (cf. Langwick 2011). The healers position themselves in relation to the claims of medical science, are interested in new knowledge and pills, but are certain that tablets will only relieve symptoms if the balance in relationships is not redressed (Wickström 2008). There is no medical clinic in Nkolokotho, and people often walk seven kilometres to the medical health clinic in Somkhele. If someone needs to consult a medical doctor, they travel 20 kilometres to Mtubatuba. However, many told me that they could not afford it. Even seeing traditional healers and buying herbs from them are too expensive for many. The nearest hospital is in Hlabisa 50 kilometres away.

KwaZulu Natal is sometimes mentioned as the epicentre of the HIV pandemic and many of the inhabitants are HIV positive or have lost family members. Others experience the benefit of free access to antiretroviral therapy. But the distribution of medicine with antiretroviral effects and vaccines has been insufficient in southern Africa. Julie Livingston's (2005) penetrating research in Botswana shows the limitations of biomedicine and how significant parts of the epidemic have been overlooked. My field assistant's case history and sudden death serve to illustrate people's vulnerability and the inadequate health care they receive. After working with me for three months, Nokuphiwe was involved in another project at the Africa Centre for Health and Population Studies. When she understood she was HIV positive, she immediately enrolled in ARV treatment through her job. Shortly afterwards she sadly passed away. When I asked one of the medical doctors who were managing the ARV roll-out in the region about this shocking experience, he estimated that one out of ten who gets treatment with ARV dies immediately because of difficulties in identifying the right kind of 
treatment. In the US, the possibility to individualize treatment is good due to the list of drugs to choose from (AIDSinfo 2012), but in the public sector in lower middle income countries, there is only one first and one second line of treatment (WHO 2011). What is more, antiretroviral therapy must be handled as chronic disease care, which requires functioning core health system structures and local capacity (Schneider et al. 2006). For antiretroviral therapy programmes to work, HIV-infected individuals have to take antiretroviral drugs regularly for the rest of their lives. Reports from 13 countries in Africa, south of Sahara, show that approximately half of the people who participate in HIV treatment programmes are no longer receiving treatment after two years (Rosen et al. 2007). Researchers studying free roll out of ARV in Botswana, Uganda and Tanzania report that people have problems continuing the treatment due to costs, hunger and the side effects of medication (Hardon et al. 2007). There is insufficient health care in Nkolokotho, and people try whatever resources are available and affordable. Here, I focus on one specific and common course of action for living a healthy life, namely that of returning home and connecting to one's family and ancestors.

In writing the present paper, I have returned to the transcripts of 58 interviews and read the passages in which people refer to the concept lungisa. In my analysis, I found that lungisa is a strategy used to restore health by putting relationships in order. The analysis process also showed that history and experiences of separation are mirrored in the representation of illness as disconnection. Finally, practices of returning and efforts to reknit unravelling communities are responses to today's political and economic situation.

\section{Illness as disconnection}

In 2007, one of my informants phoned me in Sweden and told me that she had been at death's door. Someone at her workplace in Mtubatuba had given her poison and she had been sent to Empangeni Hospital to have her appendix removed. "Well, then it was just appendicitis", I was about to say. Though I was then writing the final chapters of my monograph on health and relationships in Zululand, I still played down her story about poison as soon as I heard about her appendix. Despite the fact that I was analysing how the family members I got to know explained illness experiences in terms of optimal causes before they spoke about the proximal ones, I felt, in my worried state, that she had the wrong end of the stick. The assumption of the woman calling, and of many Zulus I have met, is that social relations are as important a determinant of people's wellbeing as individual behaviour and actions are. When things are in disorder, people attribute this state to something gone awry in the social 
interactions that make up everyday life. Even if individual failures or infectious agents are recognized as the proximate cause of many health problems, the ultimate and determining cause is almost always thought to be human agents who have actively brought about people's misfortunes. Someone at the place of work, for example, has manipulated evil, out of jealousy or envy, to destroy what has been built up. Thus, experiences of illness are not only an experience of bodily dysfunction, but one that unites bodily, psychological and social aspects. This focus on optimal causes does not mean that people deny biomedical accounts of germs and viruses, but that they try to complete a biomedical understanding with more explanatory depth. What follows is that lay theories of prevention concern relationships and being aware of risks taken in daily life when interacting with each other. One day when I was interviewing a traditional healer, a woman who passed by shouted: "Defuse jealousy now when white people visit you!" The greeting was meant to call attention to the risky business of success and others' envy. To stay healthy, a person needs to minimize others' envy.

The most important social connection is considered to be the affiliation to the family and the ancestors. People in Nkolokotho define themselves as a Dube, a Buthelezi or an Ndaba first of all. A person is part of a web of social connections and historical continuity; or rather he looks upon himself as composed of those who are close related to him, a group including both the living and the dead. People do see themselves as distinctive beings, but at the same time as intertwined with others who are part of their identity. Even when separated from them in space and time, people represent themselves as closely attached to their family and their ancestors. They are mutually dependant and they experience the effect of each other's actions. Human beings cannot refrain from taking others into consideration, as Cavarero (2000[1997]) states when theorizing selfhood.

"Every human being must know who his ancestors are, what name he bears and whose child he is". This is a statement from one of the healers I interviewed. A person becomes a human being through his or her group. When people in Nkolokotho heard about the divorce between me and the father of my two children, and about the new extended family I was living in, they concluded that $\mathrm{x}$ families are like Zulu families. But when they heard that my former husband and I shared custody of $\mathrm{x}$ and $\mathrm{x}$, and that the children moved between two homes, they started worrying about their health. "A child has to know where it belongs otherwise it will get sick." They did not stop worrying when I explained that the children in fact had two families. According to them, a child has to be interwoven into the fabric of the family. Principally, the 
child becomes affiliated with the father's descent group and not with a mother and a father. For the Zulus I interviewed, the family name and the rural homestead are the foundation of their personality and the prerequisite for good health.

A Zulu homestead is the space in which connections between persons are continuously produced over time. Thus, the home represents much more than material structure, it is the hub for continuity and health (cf. Geissler \& Prince 2010 on western Kenya). Almost every homestead has a round hut in a central place, the ancestral house. This is the most prominent place in the homestead. The first time I interviewed Ntombi, ${ }^{\text {iii }}$ a 24-year-old woman, she stressed that I needed to understand how they build their houses if I was truly interested in their way of life:

If you are a Zulu like me - I believe in God and I believe in other people that have died. If I need to talk to my grandfather I go to this hut and I speak to him about everything that I need to know. I cannot speak to a house like this [a square cement house]. You only speak to the round house and that is the Zulu culture.

Ntombi considered the central position and meaning of ancestors as priority number one to understand anything about her life. In the central hut, anyone in the family can speak to a grandmother or a grandfather who passed away not long ago, whom one remembers well and wishes to stay in contact with. Burning the Zulu herb, offering newly brewed beer and communicating in this central space of a family's life is a way of maintaining close and personal contact with one's ancestors. They are present participants and respected as old family members. The contact with the ancestors is not always ritualized; it is more like seeing each other, sitting together and communicating. On special occasions, women cook food in the hut and the smallest children crawl up and down the stone stairs, leading into the ancestors' settlement. The presence of ancestors is materialized through the hut and their participation in daily life becomes embodied knowledge in each and everyone who recurrently enters the hut, or crawls on the stairs (cf. Bourdieu 1977). People's ideologies, cognition, history and relationships are spatial and created in the homestead. The ancestral house becomes a visible and tangible expression of the origins that weaves every family member together. 
The meaning of the ancestors was impossible for many missionaries and colonizers to understand, and still today references to the ancestors are apt to be misunderstood. One of my interviewees, a woman called Mphile, explained what this led to:

People do not know where they belong or who they are. All this happens because they said that someone who is dead is dead. But you recognize that she/he is there and if he/she is very angry with you she/he can hold back all your happiness and you won't be able to do a thing.

According to Mphile, Zulu people were persuaded that ancestors were not worth caring about. It would seem to be a contradiction that representatives of Christianity, who themselves put their lives in the hands of someone they believe rose from the death, signalled that ancestors should not be taken into account or treated as present. Mphile's comment speaks about a loss of "knowing who you are" through losing connections to the ancestors. It also illustrates an understanding of causal connection. If you are not connected, your happiness may be held back. For my informants, handling relationships, not least with the living and the dead in their family fabric, is the most important factor in restoring and maintaining health. One could say that social relations are thought to determine health and wellbeing.

\section{"Lungisa" - constantly putting relationships in order}

When people in Nkolokotho speak about restoring their health or solving a problem, they use the Zulu concept lungisa to describe what they are doing. In my transcripts, I find the stem 'lung-' together with different inflected forms. It is almost always a verb with the meaning "to correct" or "to put in order" and refers to efforts to improve a person's situation when there has been disorder, or at least to make things acceptable. "If you have done wrong things and you want to do the correct things you do the ukulungisa", one 33-year-old woman explained. She stressed that it is necessary to regret what you have done: "If you don't feel you have done wrong you are not going to change anything." In the first sense, lungisa is used for managing relationships with family members on a daily basis. Harriet Ngubane (1977; 131), a native zulu speaker, emphasizes that the concept refers to a "moral order" and means to establish and maintain a form of symmetry between people. Ntombi gave me a personal example: 
I've done many bad things. It's not good but I've done it. Nobody came and paid for me and my father doesn't feel right about me. Let me go back to them and say; what I have done was wrong. I talk to my mother first and she talks to my father.

Ntombi's family experienced many difficulties. Her father was unemployed and was unable to support the family. Ntombi became pregnant without her boyfriend starting the ilobolo process. Not only was the expectant child's personality and health in danger, but also the father's role as guardian of continuity and the family's connection to the child's patrilineal family. Ntombi realized that she had failed to take care of herself and created difficulties for the family. The situation called for lungisa, which meant that Ntombi sat down with her father and tried to correct her mistakes. The boyfriend's family delivered three cows to Ntombi's father's homestead, and the act of lungisa was concrete and noticeable. But relationships need constant nourishment and have to be negotiated again and again. Ntombi became pregnant another time, but the ilobolo process did not continue. She needed to sit down with her father again and discuss her actions. These moments did not solve the problems, but they seemed to resolve disputes and alleviate tensions.

The aim of lungisa is to handle a difficult situation or, as Axel-Ivar Berglund" suggests, "to put something in such a light that it may be acceptable" (personal talk April 23, 2007). This means a constant effort to work on relationships, an ongoing process - not a single occurrence or a quick fix. By speaking out, goodwill and harmony are expressed and health may be restored (Berglund 1976). Communication though, is not only a strategy for reaching agreement, but involves efforts to acquire power in relation to others. Berglund (personal talk, April 23, 2007) heard people using the word lungisa when they hit someone as retribution for what that person had done. Ntombi's actions were not only accidents, but also an effort to create a good life:

I want to be the mother of two children and then I want to work and come back later and stay with my family only. Because my problem is that if I stay with my husband's family they'll expect me to cook, which is something that I don't want. If I want to cook I'll cook, if I don't want to cook I don't cook. If I want to sleep I sleep. I don't want to do things by force. That's why I want to stay with my children only. 
Ntombi, like many young people, saw migrant work as a preferable life and her possibility to support children, but at the same time she wished to put things in order and find a sort of symmetry. The balancing in relationships is dependent on different people's wishes and efforts and almost always comprises elements of imperfection. The goal is to improve one's existence and a state in which things are acceptable.

The second strategy of lungisa means correcting a life situation through rituals for the ancestors, and this is possibly done once in a lifetime. These rituals are imperfect strategies for handling problems by re-establishing relationships with the family, often by trying to understand what has been neglected in relation to one's ancestors. Thus, when someone in Nkolokotho travels back to her rural area, she is not on her way to something she sees as a definite solution to her ill health. She wants to understand what has happened to her, to work out which relationships are in disorder and hopefully try to turn her situation into something acceptable. Often the person has consulted a faith healer, herb specialist or diviner who has told her that the illness has been caused by her ancestors, for good reasons, in order to draw her entire family's attention to lapses in relation to the ancestors or each other, which I will exemplify in the next chapter. A consultation may end in a recommendation to slaughter cattle in order to reconnect with ancestors. As with therapeutic itineraries in rural Mali the health care experiences transform difficult experiences into some order and meaningfulness (Slobin 1998). Still, correction of a life situation does not transform life into something perfect, but highlights the shortcomings of human life, shortcomings that one may see when looking at the life course in retrospect and that could possibly be dealt with. Health is thus represented as an imperfect balance.

\section{Health through returning}

Returning is an important part of maintaining relationships. As Marcel Mauss (1997[1925]:11, 94) has shown in his classical work The Gift, a relationship gains strength and becomes extended over time through reciprocal giving and returning. A relationship is alive as long as you have reasons to return. African concepts of self and personhood stress the interdependence between people, and thus the relational aspect of a person (cf. Morris 1995). Interviewing a 19-year-old man, I asked if I needed to know anything else to be able to write my thesis. The young man answered immediately: 
It is only that the ancestors are very important to us. In everything we do we have to inform them first so that everything goes well. We have to perform some rituals for them so they can protect us. We ask for help so they can help in life and protect us so we'll be able to manage everything.

The requirement for a good relationship to the ancestors is to stay in contact with them. If the relationship with the ancestors is good, they will guide a person and provide him with the gifts he needs. If she has not informed them about his steps in life through rituals and gifts, the relationship is bad and consequently they will not be able to guide him. This may cause problems and illness. Then he has to return to the ancestors' house at the rural homestead to put things right.

If you have strict ancestors, you will face many difficulties if they have not been informed about you growing up. You will realize that they believe you are young because nobody told them you are a grown up now. This is because you have to report everything, everywhere you go. Everything you do you have to tell them.

Above, Mphile describes what happens when someone fails to perform a ritual aimed at informing ancestors about new phases in life. The ancestors would still believe he or she was in an earlier phase in life. If one informs the ancestors and stays in contact with them, then they know about one's situation and can provide guidance. Zandile is a woman in her forties who, as a young girl, followed her mother back to her maternal home to celebrate umemulo. Umemulo is an important ritual that is celebrated when a young woman has matured and is about to start courting. Very often, however, umemulo is celebrated when the woman is already engaged and about to marry. This was the case for Zandile's mother. Some rituals have to be done even if time has passed. Wellbeing and misfortune indicate the quality of a person's relationship with the family and the ancestors. To put things in order, one needs to bring these relationships into an acceptable state. One needs to return.

Each time I interviewed Gugu and her mother we were sitting in the ancestors' hut, which is painted in turquoise, beautifully situated on a hillside above the bumpy road through Nkolokotho. The first time, Gugu, who was 31 years old, told me about her efforts to lungisa. 
My son's father ran away. I don't know where he is even today. He was married and had a wife. If he had explained that before we started dating I would not have agreed. The faith healer advised me to move on because there was no hope for me. My mother told me not to lose hope, and that I should rather stay single and look for a job so that I can take care of my kids.

When Gugu started to lungisa she was advised not to fight for getting the boyfriend back. Later she managed to get a job in town. However, she was severely ill at times, and my understanding was that she had HIV. She returned home. A neighbouring woman explained to me: "You ask the ancestors to apologize after doing the wrong things. But then you have to do the right things. You do the ukulungisa. If you have the flue you don't go back home, only if it is a serious thing." When I asked her if it was possible to talk to the ancestors in town, she exclaimed: "No, no, no. This is not my home. They are not allowing me to talk to them. You have to do it in your family." The "health-seeking journeys", especially for serious things, go along the urban rural route (cf. Flikke 2001). Flikke (2001), who has joined several such journeys, argues that the practice was imposed on people by the colonial regime and is used by many Zulus. In Nkolokotho, people are dependent on a domestic economy of care. I followed Gugu and her care-giving mother through various periods of health and disease, migrant work and confinement in bed, despair and hope (cf. Geissler \& Prince 2010). The last time I visited them was in September 2011, and I was happy to find that Gugu was not at home, a sign that she still was surviving on ARV and was able to send wages home to her parents and children (cf. Livingston 2005; 238). Their aging neighbours had only one son left of the four they once had and were living with only their grandchildren, without any support. AIDS and divided families have created rips in the fabric of the family. Gugu's narrative speaks about restoration of health and a strong connection to a place and to a group of people related to that place.

Cavarero (2000[1997]) uses the concept "the narratable self". She does not understand it as a philosophical subject that tells her story through introspection. Rather the narratable self tells her story through his actions. Many people from Nkolokotho live in big cities far from their rural homestead. Their connections with the homestead are part of them even if they are not spatial. While in good health, people can manage to stay away from home. But after falling ill, they wish to bring together what has been separated. They leave town and the job in order to "hold together the elements of their living world" (Cavarero 1995[1990]:29). Instead of 
looking at acts of returning as irrational behaviour, they may be seen as creating a narrative of the self - a narrative of separation and of connectedness. Lungisa is a way of being in the world, of being allied with a greater whole, and negotiating important relationships and continuity with others.

Healing and medicine in Nkolokotho are aimed at connecting people. Nicholas is a traditional healer whose laboratory is built beside road 618 by the crossroads of Somkhele. His house is situated opposite the medical health clinic, and it has "Come to life-pharmacy" painted on it. Nicholas showed me his book of recipes for traditional medicines. The herbs were named according to what effects they were supposed to create. Many ingredients were related to this notion of returning. Some examples were "look for the one who left long ago", "call somebody back home", "know that you are needed at home" or "concentrate on me only". Nicholas explained how the herbs worked on people's heart, causing them to start thinking about their family. The focus on health as being connected express a specific representation of the self, but also historical experiences of separation and of today's daily life. The division between two social worlds that many Zulus experience, ever since the segregation laws and industrialization, is mirrored in how the informants handle illness and that they consider the native land to be important for curing.

People in Nkolokotho want more doctors and access to biomedical treatment, but they still consider returning "the big medicine". Even if a person starts ARV treatment he needs to return: "You are taking the tablets, but you are not going to recover. It's very important to go back home. Going back home to the family is 'the big medicine'. It goes into the heart", Ntombi explained. To quote Livingstone, people move between categories of medical knowledge but maintain a "discursive continuity around issues of health and the human body" (2007; 807). When Ntombi gives precedence to "the big medicine", she moves between systems but help consolidate each of them (ibid. p. 810).

\section{Weaving space and relationships}

Acts of returning seem to disturb linear thinking or the empiricist theory of how the natural world is (Good 1994). Returning evokes images of useless and unproductive work, like when Penelope undoes in the evening what she has woven during the day to keep her linen unfinished and to avoid being forced to choose one of her suitors. When Gugu leaves her job and returns to her rural area, that course of action and that place seem more important to her 
than the next few weeks in town. She is part of a larger historical continuity. As with Odysseus and Penelope, we can see what counts as action; it is not what is going on in the private sphere. Home is often characterized by the absence of action owing to the endless repetition of actions. Penelope does not produce what is expected of her, namely a set of linen, but she produces time and exerts control over her situation. Analogous to this action, people who return produces a space and relationships to exert some control and to counteract the forces that have created their living conditions.

Practices of returning and concerns with family values are not useless or irrational, but creative and vital when examining the intersection of people's experiences, structural constraint, and the cultural meanings attached to the rural area and the ancestors. A final concept from Cavarero is useful here; namely her notion of "weaving together". The scandal in the myth is not that Penelope unravels what she has woven, but that she reweaves what she has already unwoven. She returns to the same work over and over again. Cavarero (1995[1990]) argues that, by endlessly weaving and unravelling, Penelope, in fact, weaves something together. She holds together the elements of the living world. Similarly, in my thesis, I theorized the family as a woven fabric that is central to health (Wickström 2008), and Devisch (1993 on the Yaka in Zaire) considers healing a reweaving and interweaving of the physical body, the family and the life-world. Cavarero's concept adds that weaving is a strategy to define one's time and space, and to snatch them from the events that try to draw people back into a symbolic order not of their own making. People returning to Nkolokotho "weaves together" and react against an order they do not recognize as theirs. Colonial rule, the apartheid system and migration work have created a void in their life. When someone experiences illness, he returns to his ancestral home and start weaving space. He is held together as an individual, together with other individuals, in a mutually collective action. When returning, people reknit unravelling communities, families and persons. They show where they belong and that well-being and healing are connected to a social world with somewhat secure relations and collective histories. Lungisa, or the constant act of balancing and returning, is a way of being in the world, allied with a greater whole, weaving a space without producing anything tangible.

\section{References Cited}


AIDSinfo 2012 Guidelines for the use of Antiretroviral Agents in HIV-1-Infected Adults and Adolescents. http://aidsinfo.hih.gov/guidelines, accessed June 15, 2012.

Berglund, Axel-Ivar

1976 Zulu Thought-Patterns and Symbolism. Bloomington: Indiana University Press.

Bourdieu, Pierre

1977[1972] Outline of a theory of practice. Cambridge: Cambridge University Press.

Bryant, Alfred T.

1970[1949] The Zulu people as they were before the white man came. New York: Negro

Universities Press.

Carsten, Janet

2004 After Kinship . Cambridge: Cambridge University Press.

Cavarero, Adriana

1995[1990] In Spite of Plato. A Feminist Rewriting of Ancient Philosophy. Cambridge:

Polity Press.

Cavarero, Adriana

2000[1997] Relating Narratives. Storytelling and Selfhood. London: Routledge.

Comaroff, John L., and Jean Comaroff

1997 Of revelation and revolution: Christianity, colonialism and consciousness in South

Africa. Vol. 2, The dialectics of modernity on a South African frontier. Chicago: University of Chicago Press.

Devisch, René

1993 Weaving the Threads of Life. The Khita Gyn-Eco-Logical Healing Cult Among the Yaka. London: The University of Chicago Press.

Du Preez, Corrie, and Anke Niehof 
2008 Caring for people living with AIDS: A labour of love. Medische Antropologie 20(1):87-104.

Fanon, Frantz

1967[1952] Black skin, white masks. New York: Grove Press.

\section{Feierman, Steven}

1999 Colonizers, Scholars, and the Creation of Invisible Histories. In Beyond the cultural turn: New Directions in the Study of Society and Culture. Victoria.E. Bonnell and.Lynn Hunt, eds. Pp. 182-216. London: University of California Press.

Flikke, Rune

2001 Curing the Ills of History; From colonial public health to hygiene and healing in contemporary South African Independent Churches. Ph.D. dissertation, Department of Social Anthropology, University of Oslo.

Geissler, Paul Wenzel and Prince, Ruth Jane

2010 The Land is Dying; Contingency, Creativity and Conflict in Western Kenya. Oxford: Berghahn Books.

Good, Byron J.

1994 Medicine, rationality, and experience. An anthropological perspective. New York:

Cambridge University Press.

Hardon, Anita P., et al.

2007 Hunger, waiting time and transport costs: time to confront challenges to ART adherence in Africa. AIDS Care 19(5):658-65.

Honkasalo, Marja-Liisa

2009 Grips and Ties: Agency, Uncertainty, and the Problem of Suffering in North Karelia. Medical Anthropology Quarterly 23(1):51-69.

Hunter, Mark 
2002 The Materiality of Everyday Sex: thinking beyond 'prostitution'. African Studies 61(1):99-120.

Langwick, Stacey A.

2011 Bodies, Politics, and African Healing. The matter of maladies in Tanzania.

Bloomington: Indiana University Press.

Livingston, Julie

2005 Debility and the Moral Imagination in Botswana. Bloomington: Indiana University

Press.

Livingston, Julie

2007 Productive Misunderstandings and the Dynamism of Plural Medicine in Mid-century

Bechuanaland. Journal of Souther African Studies 33(4):802-810.

Mauss, Marcel

1997[1925] The gift: the form and reason for exchange in archaic societies. London:

Routledge.

Morris, Brian

1995 Anthropology of the Self. The Individual in Cultural Perspective. London: Pluto Press.

Ngubane, Harriet

1977 Body and Mind in Zulu Medicine: An Ethnography of Health and Disease in Nyuswa-

Zulu thought and practice. London: Academic Press.

Niehaus, Isak

2002 Bodies, heat, and taboos: Conceptualizing modern personhood in the South African Lowveld. Ethnology 41(3):189-207.

Parle, Julie, and Fiona Scorgie

2001 Bewitching Zulu Women: Umhayizo, Gender, and Witchcraft in Natal. Paper presented ad the 44th Annual African Studies Association Meeting, Houston. November 1518. 
Rosen, Sydney, Matthew P. Fox, and Christopher J. Gill

2007 Patient retention in antiretroviral therapy programs in sub-Saharan Africa: a systematic review. PLoS Medicine 4(10):e298.

Sahlins, Marshall

2011 What kinship is (part one) Journal of the Royal Anthropological Institute 17(1):2-19.

Schneider, Helen et al.

2006 Health Systems and Access to Antiretroviral Drugs for HIV in Southern Africa: Service Delivery and Human Resources Challenges. Reproductive Health Matters 14(27):12-23.

Slobin, Kathleen 1998 Repairing Broken Rules: Care-Seeking Narratives for Menstrual Problems in Rural Mali. Medical Anthropology Quarterly 12(3):363-383.

Strathern, Marilyn

1988 The gender of the gift: problems with women and problems with society in Melanesia. Berkeley: University of California Press.

\section{Welsh, David}

1971 The roots of segregation: native policy in colonial Natal, 1845-1910. Cape Town,

London, New York: Oxford University Press.

White, Hylton

2001 Tempora et Mores: Family Values and the Possessions of a Post-Apartheid

Countryside. Journal of Religion in Africa XXXI(4):457-479.

\section{Wickström, Anette}

2008 Love in the Time of the Virus: Managing Relationships and Health in Zululand. Ph.D. dissertation, Linköping University, Sweden. 
2010 Virginity testing as a local public health initiative: a 'preventive ritual' more than a 'diagnostic measure' Journal of the Royal Anthropological Institute 16(3):532-550.

\section{World Health Organization}

Annual 2010 Survey on ARV Use and Trends in Implementation of WHO 2010 ART

Recommendations. WHO \& UNAIDS Annual Consultation With Pharmaceutical

Companies - Global Forecasts of Antiretroviral Demand 2011-2012. Geneva, 9-10

December 2010. 

${ }^{\mathrm{i}}$ The study granted ethical clearance by Human \& Social Sciences ethics sub-committee at University of KwaZulu-Natal in South Africa on February 10, 2004.

${ }^{\text {ii }}$ My academic residence was the Africa Centre for Health and Population Studies in Hlabisa district, financed by the Wellcome Institute. I discussed my research with the Community Advisory Board and presented my initial analysis at seminars of the Population Studies Group.

iii The interviewees have been given pseudonyms.

${ }^{\text {iv }}$ Berglund grew up in a missionary family in Ekutheleni in Zululand and later did fieldwork for his dissertation on Zulu symbolism (1976). 